\title{
Escherichia coli: A disease in the news through speeches of uncertainty and contradiction
}

\author{
Felisbela Lopes, Teresa Ruão, Sandra Marinho, Rita Araújo \\ Communication and Society Research Centre, University of Minho, \\ Braga, Portugal
}

\author{
Correspondence to: \\ Teresa Ruão, \\ Communication and \\ Society Research Centre, \\ University of Minho, \\ Campus de Gualtar, \\ 4710-057 Braga, \\ Portugal. \\ truao@ics.uminho.pt
}

\begin{abstract}
In May 2011 there was a rare outbreak of E. coli in Germany, and its origin was not clear. Through several weeks, official sources came forward with probable explanations that were contradicted by the following events. Through that time, media kept contradicting themselves, promoting uncertainty and making vegetables' consumption decrease drastically. This article studies the Portuguese media coverage of this outbreak, looking into understanding the news coverage processes and also sources journalists talked to. Our study is based on news from Público, Jornal de Notícias and Expresso, three Portuguese newspapers with different editorial criteria and periodicity. Our corpus has 52 articles and there are 163 news sources quoted.
\end{abstract}

Keywords: health journalism, crisis communication, risk communication, disease, news sources

\section{Introduction}

In May 2011, there was a rare outbreak of Escherichia coli in Germany. E. coli is a haemorrhagic disease and it caused 48 deaths in the country in a short period of time. Authorities came forward with several explanations, which were contradictory, in different phases of the risk and crisis management that was installed afterwards. The initial cause of the outbreak pointed out to the consumption of Spanish cucumbers, but that was not confirmed. Authorities kept announcing new (and wrong) explanations, as the consumption of other raw vegetables, like sprouted seeds or Greek hay seeds. Therefore, there was a disoriented communication with instructions to protect European population, particularly the ones living in Germany. Media would amplify contradictory news on a daily basis, quoting official sources. In Portugal, the outbreak's news coverage would echo an eventual contagion of Portuguese people (both nationally and internationally) and the effects that international alerts could have on national exportations.

In this paper, we study the Portuguese media coverage of $E$. coli infectious outbreak, a disease in the news through a discourse highlighted by uncertainty and contradiction. Our analysis was based on three National newspapers - Público, Jornal de Notícias, and Expresso - in the period between 27 May 2011 and 7 July 2011. We have a corpus of 52 news pieces. This analysis shows a journalistic work made of probable causes, fed by institutional sources (mainly international) who did not correspond to the informative needs or population protection requirements.

\section{Context remarks}

In between risk and crisis

To understand the news coverage about $E$. coli outbreak we need to analyse the risk/crisis communication processes. Actually, news production suggests an amount of proceedings promoted by different entities on this subject, and it shows an influence of strategic communication procedures (or a lack of them).

Specialized literature highlights the importance of distinguishing between risk communication and crisis communication, as two different but complementary specific areas of expertise. Risk communication is traditionally associated with health communication and the efforts developed by different institutions in order to prevent people about risks associated with certain behaviours or environmental hazards. On the other hand, crisis communication has to do with public relation activities and the communicative efforts one needs to do (either it is a company/institution/brand) to prevent or repair 
perceptions during or after a crisis/disaster situation. $^{1-4}$

Thus, one of the main differences between risk and crisis communication has to do with their origins. Risk communication is related to the identification of public health risks and the subsequent efforts in order to persuade the public to adopt healthy, risk-free behaviours. Crisis communication is connected to the effort made in order to manage and strategically define the public's perceptions, as to reduce the crisis damages either to organizations or to stakeholders.

However, some authors stand for the importance of combining these two areas in public health hazards management. Reynolds and Seeger $^{2}$ suggest a practice named 'crises and emergency risk communication' (Crises and Emergency Risk Situation - CERC; Reynolds, 2002) as a model of act capable of managing different communicative needs towards different audiences and multiple demands in distinct phases of a threat or critical event. From the combination of risk and crisis communication practices came the consideration of a five stage model: risk, eruption, cleaning, reconversion, and evaluation.

When it comes to health, these stages can be a sequence in a public health alarm situation. Health risk communication can become a crisis communication situation, when risk is not controlled and the situation gives place to a public health crisis. When this happens, one of the essential elements seems to be the development of communication plans capable of empowering authorities' confidence and their ability to produce reliable act orientations towards the public problem.

Therefore, authors draw attention to the importance of developing healthy relationships between organizations and media before, during and after certain events. ${ }^{5}$ Media spread information fast, and they usually repeat it; that is why they are so useful in providing information to people in a risk or crisis situation. However, one needs to have in mind that those informative messages should be followed by education, motivation, confidence, or protection concerns. ${ }^{6}$

Some researches point out to dangers associated with media communication in a risk/crisis situation. ${ }^{6,7}$ Due to the urgency of these kind of issues, press office work tends to be less prepared than usual. Press officers typically send briefings, make press conferences, or public announcements; these are fast ways of presenting information, but they are more subject to diffusion mistakes than written communication. On the other hand, being the themes so complex, the need to cross sources and depositions, and rush in having media information may contribute to transmitting inaccurate or contradictory messages.

During the process, the relationship between journalists and sources becomes difficult. As referred by Atkin and Wallack ${ }^{8}$ (p. 16), 'media are an essential part of public health information dissemination process, but the relationship between health professionals and media is not always peaceful. Media and public health institutions have conflicting priorities'. Authors say that this conflicting situation may lead to a frustration condition in the way media cover health issues, often led by times and agendas that influence the message. Seale 9 (p. 52) refers 'two cultures' that create 'tensions between the journalists' world and the scientists' world'.

Towards a threat, there is a growth of different communicative demands and needs. This context asks media and organizational actors an uncommon answer timing. Within a risk or crisis situation, as the recent E. coli outbreak in Germany, it seems to be essential that both media and health professionals cooperate in order to avoid panic on people and manage minimizing risks and consequences. In this puzzle of responsibilities, literature highlights the importance of increasing the public's trust level in governments' politics. Either by the way organizations communicate with each other, or the way media reproduce messages. Without that confidence factor, risk/crisis may be worse, as well as the consequences to people. Actually, 'natural and manmade disasters, from hurricane Katrina to 9/11 terrorist attacks or the more recent fires in California, have shown the importance of the public's devotion to Government's health and security norms' (p. 60). ${ }^{10}$ Different authors stress out that not following governmental norms in emergency situations may put public health directly at risk.

To enhance the answer timing of people in public health emergency situations, some communication models have been developed (as CERC), which look into improving risks and crises management within the defiant globalized contexts. Emergencies' nature, levels of threats, and the constant and omnipresent media coverage seem to demand more comprehensive approaches to communication and to the development of more reliable media information systems.

E. coli

E. coli bacterium is usually found in human and animal bowels, but according to the World Health Organization (WHO) (http://www.euro.who.int/ en/what-we-publish/information-for-the-media/ 
sections / latest-press-releases / germany-investigatesoutbreak-of-haemolytic-uraemic-syndrome) most of E. coli strains are harmless. It is transmitted to humans mainly through the consumption of contaminated food, as raw or undercooked meat and milk. The first E. coli outbreak happened in the United States in 1982, and it was then that this bacterium was recognized as a potential public health problem.

In May 2011, Germany was involved in an E. coli outbreak with a rare serotype named 0104: H4, which produces toxins known as Shiga or verotoxins and causes a disease named enterohaemorrhagic E. coli (EHEC). This disease's symptoms are abdominal cramps and bloody diarrhoea (haemorrhagic colitis), and it may cause fever and vomittings. Most patients infected with this strain of E. coli recover within 10 days, but in a small percentage of patients, especially children and elderly, the infection may lead to a life-threatening disease, such as haemolytic-uremic syndrome (HUS). This syndrome is characterized by acute renal failure, haemolytic anaemia, and thrombocytopaenia (low number of platelets in the blood). It is thought that around $10 \%$ of patients with EHEC may develop HUS.

WHO classifies this outbreak, in 2011, as 'uncommon' due to its fast growth and the fact that it does not affect the usual risk groups: children and elderly people. On 27 May 2011 WHO wrote on its website (http://www.who.int/csr/don/2011_05_27/en/index. $\mathrm{html}$ ) that 'the epidemiological research to find out the source of the outbreak is going on'. It went on: 'Though the source has not been determined yet, cucumbers are the suspects and Robert Koch Institute in Germany is warning people, as a preventive measure, to avoid eating tomatoes, cucumbers and lettuce, besides taking the usual hygiene precautions when handling fruits and vegetables'. According to Health International Rules, Germany notified WHO of this outbreak, saying this was 'a potential public health situation that deserved international concern'. On its last note on E. coli outbreak (http://www.euro.who.int/en/what-we-do/healthtopics/emergencies/international-health-regulations/ news/news/2011/07/ outbreaks-of-e.-coli-o104h4infection-update-30, 22th July 2011), WHO announces that 16 countries (in Europe and North America) have reported cases of infection with this bacterium.

HUS originated 908 cases and 34 deaths; EHEC originated 3167 infectious cases and 16 deaths. Germany was the most affected country: 908 people were infected with HUS and 34 died; EHEC infection originated 3167 cases and 16 deaths (Data from WHO, report from 21 July 2011, 18h00 CET).

\section{Methodology}

This research is part of a wider project on Portuguese media coverage of diseases (Lopes et al., 2009). ${ }^{11}$ This research pretends to study the media coverage of an outbreak which is news through an uncertain discourse. This work is based on a double axis:

- The analysis of news themes produced since the beginning of the outbreak until the epidemic was declared controlled.

- The analysis of news sources, made through seven variables: presence/absence of sources; number of quoted sources; geographical place of the source; gender; identification; status; and medical specialty.

Most of all, this is a mapping and extensive vocation research, so our priority was the quantitative analysis of data, centred in univariated descriptive statistics. These options have to do with the main goal of the global research being a mapping of regularities, since we did not formulate explicit hypotheses or the consequent measurement of variables association.

As for the selection of the units of analysis, and the choice of media, we chose non-probabilistic sampling. First of all, we chose press information, leaving aside television, radio, and online media. This was just a matter of convenience, given the resources we have available in this phase and the easier access to data. We chose general press because the project goals are to evaluate, among others, the relevance (from the number of news) media gave to E. coli outbreak amongst everything that was news in the country. This makes specialized press inadequate as a unit of analysis. When it comes to choosing Expresso, Público, and Jornal de Notícias (a weekly broadsheet, a daily broadsheet, and a daily popular), this is a typical case sampling. Different periodicity points out to the implicit hypothesis, yet not strictly measured in his phase of analysis, that there may be differences either because of the periodicity, or in other hypothesis, due to the editorial line being popular or broadsheet. These are implicit hypotheses, yet not measured in his phase of the research, as we had already referred.

The period selected for analysis is coherent with the theme's emergency criterion: between May and July 2011. During that time, Público published 21 
texts on E. coli, Jornal de Notícias (JN) 27, and Expresso four. Then, we have a corpus of 52 articles, which analysis we will explain.

\section{The $E$. coli case: constructing the news process}

In Portugal, E. coli outbreak's news production can be divided in four phases: the outbreak is associated with Spanish cucumbers, which would be 'allegedly dangerous'; a few days after that, the suspicion is spread to other vegetables; on a third phase the cause of the outbreak is said to be in sprouted seeds/beans; in the end the news say the 'probable cause' would be Greek hay seeds brought from Egypt. All these explanations are presented as probabilities. There are no facts, but possibilities presented as news.

\section{The allegedly dangerous Spanish cucumbers}

The Portuguese press starts to report the E. coli outbreak in Germany on 27 May 2011. One can read that the German Ministry of Agriculture 'allegedly says' Spanish cucumbers would be 'the source of a fatal infectious outbreak in his territory' (JN, 27 May). The news say cucumbers were sold in Hamburg's central market and, according to German authorities, they would be responsible for three people dying and another 600 getting infected. The news title was: 'Portugal does not import deathly cucumbers'. On the following day, 28 May, news came forward with the possibility of Spanish cucumbers not being the cause of the infectious outbreak. Portuguese press quoted several national official sources who contradicted the previous day's information. The Portuguese Ministry of Health and Ministry of Agriculture assured that Portugal would be protected from the outbreak that is said not to be Spanish (JN, 28 May). Although titles clearly deny the previous day's facts, media speech is unsure: 'it seems unlikely that exported Spanish cucumbers be the source of the infectious outbreak' (JN, 28 May). Portuguese Economic and Food Safety Authority begins an inspection on Spanish cucumbers. Uncertainty begins.

Several news are published, with three main themes:

- They report the growing number of deaths or patients who are suspects of being infected in several countries ('There are 1500 people sick in Germany', Público, 2 June 2011; 'Three Portuguese suspects of infection in Germany', Jornal de Notícias, 3 June 2011).
- The commercial impact of the outbreak's news coverage on the sales of cucumbers ('Price decreases 35 cents in production', Jornal de Notícias, 31 May 2011; 'Consumers are afraid to eat vegetables due to $E$. coli outbreak', Público, 4 June 2011).

- The uncertainty as for the infection's origin ('Portugal analyzes cucumbers to find out bacteria', Jornal de Notícias, 2 June 2011; 'There are still not clues on the food that is causing this disease', Público, 3 June 2011).

News coverage shows two contrary reports: internationally, there is a wide sense of fear ('Infectious outbreak caused by bacterium detected in cucumbers causes panic in Europe', Público, 30 May 2011); nationally, the concern is to keep a calm and positive speech (Francisco George, head of the National Health Board, says the situation in Germany is 'very disturbing', but puts Portuguese to rest and says 'the problem is limited [to Germany]', Jornal de Notícias, 31 May 2011; 'Francisco George stressed out that notified cases were what we had expected', Público, 3 June 2011).

However, other countries in Europe have more alarming positions, ending the importation of Spanish cucumbers. Like Belgium, Czech Republic and Austria took the product from their markets, while Russia went further and imposed an embargo to Spanish and German vegetables' importations.

\section{Other vegetables under suspicion in an uncertain context}

News speech highlights not only the cucumbers but also other probable causes for this infectious outbreak. On 31 May 2011, Público publishes this: 'Other vegetables that can be eaten raw, like tomatoes and lettuces, are also under suspicion in Northern Germany'. However, there is never a certain speech. Portuguese press is usually careful when covering E. coli, with journalists ending up using expressions like 'it seems that', 'all points out to', 'eventually' etc.

One can read on Público's edition from 2 June 2011 that 'German health authorities have to do a real detective job to find out the source of E. coli 0104:H4'.

On the day after, other news says that the bacterium that is infecting people in Germany 'seems to be a new strain of Escherichia coli'. But there are no certainties: 'German and Chinese laboratories confirmed this is a new strain; but WHO sends a confused message: is it a new strain or just another "very rare"?" The origin of the infection is still 
unknown, but the 'most likely hypotheses' are the consumption of raw vegetables undermined by $E$. coli or non-treated water, one can read.

WHO reports, on Público's 5 June 2011 edition, there is a possibility that E. coli contagion may happen by direct transmission, meaning person-toperson transmission. Yet, 'the source of the contamination remains unknown'. Given this uncertainty, national speech, through National Health Board, keeps undervaluing the case. The three Portuguese people who came back from Germany are still under suspicion of infection, but the head of National Health Board says 'there is a risk, though small' (Jornal de Notícias, 3 June 2011). Francisco George keeps telling that 'there are no cases, there are people who felt sick', repeating the positive calm tone which ends up characterizing national speech.

\section{The vegetable seeds hypothesis and a mistaken communication strategy}

On 6 June 2011, Portuguese press comes forward with another possibility related to the origin of the outbreak. Público writes that sprouted seeds/beans would be 'the probable origin' of E. coli outbreak. Yet, there is no definitive evidence when it comes to this hypothesis. Gert Lindemann, Health Minister the Low Saxon, says 'evidence are strong enough to recommend consumers not to eat sprouted seeds'. The communication strategy in Germany seems to be, up until now, non-existent. Authorities keep coming forward with non-confirmed hypotheses for E. coli's origin, alerting people not to consume the allegedly dangerous food and causing damages in agriculture and economy all over Europe. On the following day, Público publishes news that states the first tests done to sprouted seeds were negative as for the presence of $E$. coli.

On 8 June, the same newspaper focuses on the consequences of this outbreak for the European economy: 'Although cucumbers were (...) innocent as the bacteria's most dangerous outbreak's origin, Hanover authorities have disapproved its consumption, and the same goes to European tomatoes and lettuces, causing panic and a drastic decrease in vegetables' consumption'. Crisis management is qualified as 'mistaken' by the European Health Commissioner, who criticizes the fact that we still do not know what E. coli's origin is' (Público, 6th June 2011). German authorities alert related to Spanish cucumbers has proved to be, according to the same news, 'premature and lacking enough scientific base'.

On 10 June, Portuguese press says sprouted seeds' clue has changed country, with Dutch authorities announcing the discovery of E. coli on beetroot sprouts. But, again, there were no certainties on the causes.

Probabilistic news keep coming, with Público writing that Germany 'believes' sprouted seeds/ beans are E. coli's origin. The news says researchers detected 'infallible evidence' on a farm in Low Saxon, which is the 'most probable' cause for the outbreak, according to German authorities. Russia promises to stop the embargo to European Union vegetables, though they do not say when.

Jornal de Notícias publishes a news on sprouted seeds on 11 June ( 5 days after that was news on Público), saying that the outbreak's 'probable origin' was identified. The news is based on probability: 'Even though there are no laboratory confirmations, all points out to the fact that the outbreak's source is a biological agriculture farm in Bienenbüttel, Low Saxon'.

Towards these eventual causes to an outbreak, the responsibility of which was initially pointed out to Spain, newspapers progressively criticize German authorities. Without quoting a news source, Público's edition on 12 June states:

The outbreak caused panic and convulsion in Germany, and made relationships with European neighbours tense, with authorities pointing out responsibilities to Spanish cucumbers. The country's image rehabilitation (this country was an example of efficiency and accuracy) will have to deal with criticisms on the delay in identifying the outbreak's source and giving accurate information to consumers.

All over Europe there are fails pointed out to Germany's crisis management, which spread the alarm on consumers without having precise evidence for E. coli's origin. In the mean time, in Thailand, health authorities announced to have found $E$. coli in cauliflowers imported from Europe. On 16 June, Jornal de Notícias says another elderly died, referring that 'German health authorities' act is internationally and domestically criticized'. Russia keeps the embargo to European Union, since German authorities do not have a proved cause and there are no evidences that the outbreak will end soon.

Público publishes one last piece of news on E. coli on 17 June, saying seven children got sick in Northern France, due to severe food poisoning caused by a 'rare strain' of E. coli. This happened after they ate frozen hamburgers sold by Lidl supermarkets. However, French authorities assure that 
this is not the same serotype that is damaging Germany. Público breaks its news production on E. coli, stopping news pieces on an outbreak that is not finished. Jornal de Notícias publishes some news on the French children who go to the hospital, coming forward with different numbers from Público: six children, instead of seven. Francisco George (head of National Health Board), talking about Portugal, criticizes Germany's way of acting, saying there were 'a lot of communication errors', mainly due to 'the lack of consistency and speed' in the authorities' initial answer.

\section{An outbreak that ends with a 'probable cause'}

From 21 June onwards, Portuguese press begins a turn-around in the kind of news they had been doing on E. coli. On that day, news say 'two children infected with E. coli have already got better' (Jornal de Notícias). On the day after, the same newspaper says 'Russia may stop embargo to vegetables' (Jornal de Notícias). On 28 June, Jornal de Notícias says 'health authorities from several countries, namely the Netherlands and the United Kingdom, are more and more sure that E. coli outbreak, that until yesterday had caused 47 deaths, is connected with the consumption of raw or undercooked vegetables'. All these news pieces are small, and there are not many news sources quoted.

It is only on 5 July that Jornal de Notícias says the outbreak is nearing the end in Germany. The news is based on a press release from Robert Koch Institute, which says there are 'several evidences that point out to the end of the infectious outbreak'. The European Food Safety Agency (EFSA) declares that some Greek hay seeds bought to Egypt by Germany in 2009 'seems' to be responsible by the E. coli outbreak. Consequently, the European Union announced the 'temporary prohibition of all imports of sprouted seeds/beans and Greek hay seeds from Egypt'. Two days after that, on 7 July, Jornal de Notícias writes that EU declares the outbreak is controlled. The head of Health and Consumption from European Commission is the main source of this news, having declared to the Spanish wire Efe that 'the situation is totally under control, since the source of the infections is known and neutralized'.

Journalistic speech points out to 'Greek hay seeds from Egypt' as a 'probable cause' and not the definitive cause, which is curious. On 26 July, Robert Koch Institute (federal agency for combating diseases) declares the end of a rare strain of E. coli's outbreak. This outbreak led to the death of many people in Europe. During all the process, uncertainty dominated this outbreak's causes.

\section{Who talks about E. coli in Portuguese press? Some results}

On E. coli's news coverage, most analyzed articles present news sources: 9 in Expresso; 66 in Jornal de Notícias; 88 in Público. Usually there are three sources per article (Corpus: Público $=21$ news pieces; Jornal de Notícias $=27$; Expresso $=4$ ).

Most texts are medium sized and they do not promote a plurality of news sources, mainly nationally. When it comes to national sources, journalists often talk to the same sources, who are usually official. There is a kind of news sources brotherhood that promotes somewhat predictable news coverage. Internationally, there is a greater diversity of sources, and quotations are usually made through other media.

On analysed newspapers, more than half the sources are identified, meaning that we know their name, their status and the place they come from (see Table 1).

Texts on E. coli do not quote anonymous sources, but there is a significant percentage of unidentified sources. These are the ones we do not know the name of, but who talk from an institution or company (e.g.:'doctors from Lille hospital', Público, 17 June 2011; '... according to WHO', Expresso, 18 June 2011; '... has confirmed to Jornal de Notícias a source from the Agriculture Ministry', Jornal de Notícias, 31 May 2011). This is not a common characteristic on health journalism in the Portuguese press, which is usually made of identified sources. ${ }^{12}$ Nonetheless, the uncertainty context that characterizes this outbreak is ideal to understand the difficulty a certain source has in assuming any information personally. News sources do it, but in the name of a group, an organization: National Health Board, German Agricultural Confederation...

Portuguese press used a lot of sources outside health field on E. coli news. Journalists used sources within the field when they were official, like the Ministry of Health, head of National Health Board etc. These sources are within a small group of people (Table 2).

Table 1: Sources identification on E. coli's news pieces

\begin{tabular}{lccc}
\hline & $\begin{array}{c}\text { Expresso } \\
(\%)\end{array}$ & $\begin{array}{c}\text { Público } \\
(\%)\end{array}$ & $\begin{array}{c}\text { Jornal de } \\
\text { Notícias (\%) }\end{array}$ \\
\hline $\begin{array}{c}\text { Identified } \\
\text { sources }\end{array}$ & 66.7 & 76.1 & 65.2 \\
$\begin{array}{c}\text { Unidentified } \\
\text { sources }\end{array}$ & 33.3 & 23.9 & 34.8 \\
\hline
\end{tabular}


Table 2: Sources status on E. coli's news pieces

\begin{tabular}{llccc}
\hline & Sources & $\begin{array}{c}\text { Expresso } \\
(\%)\end{array}$ & Público (\%) & $\begin{array}{c}\text { Jornal de Notícias } \\
(\%)\end{array}$ \\
\hline Health field & $\begin{array}{l}\text { Official sources } \\
\text { Specialized and institutional } \\
\text { sources }\end{array}$ & 55.6 & 26.1 & 24.3 \\
& $\begin{array}{l}\text { Specialized and non-institutional } \\
\text { sources } \\
\text { Documents }\end{array}$ & 0 & 4.5 & 3 \\
& Other sources & 11.1 & 2.2 & 3 \\
$\begin{array}{l}\text { Outside health } \\
\text { field }\end{array}$ & & 0 & 3.4 & 10.6 \\
\hline
\end{tabular}

One may say that Expresso does not tend to listen to people within the health field; in this weekly newspaper more than $50 \%$ of sources are official and belong to the health field. However, this newspaper cannot be a representation of Portuguese news coverage, due to the absence of a wide range of texts published on E. coli. On this subject, Público and Jornal de Notícias seem to be more representative. They usually talk to sources outside the health field.

Although health journalism in the Portuguese press often resources to a fair number of documents, ${ }^{12}$ this outbreak did not motivate the quotation of many documents. Official sources did not promote many press releases and specialized sources did not develop many researches.

There are not many specialized sources, either institutional (sources who talk on behalf of an institution) or non-institutional (sources who talk on behalf of themselves). Specialized and institutional sources, as hospital service directors or research centre directors, are not represented in the weekly newspaper. The same happens with documents.

Politics and media or news websites are the most quoted sources outside the health field. Therefore, this kind of source is the one that journalists seem to talk to when they want someone outside the health field.

Apart from Expresso, analysed newspapers show a trend to prefer international sources over national ones. Most of the sources used by Expresso are national, a phenomenon that can be explained by the low news coverage on E. coli. This preference by international sources is easily explained by the facts: the outbreak affected mainly some European

Table 3: Sources geography on $E$. coli's news pieces

\begin{tabular}{lccc}
\hline & $\begin{array}{c}\text { Expresso } \\
(\%)\end{array}$ & $\begin{array}{c}\text { Público } \\
(\%)\end{array}$ & $\begin{array}{c}\text { Jornal de } \\
\text { Notícias }(\%)\end{array}$ \\
\hline National & 66.7 & 22.8 & 34.8 \\
International & 33.3 & 76.2 & 62.1 \\
\hline
\end{tabular}

Table 4: Sources gender on E. coli's news pieces

\begin{tabular}{lccc}
\hline & $\begin{array}{c}\text { Expresso } \\
(\%)\end{array}$ & $\begin{array}{c}\text { Público } \\
(\%)\end{array}$ & $\begin{array}{c}\text { Jornal de } \\
\text { Notícias }(\%)\end{array}$ \\
\hline $\begin{array}{c}\text { Male } \\
\text { sources }\end{array}$ & 55.6 & 31.8 & 34.8 \\
$\begin{array}{c}\text { Female } \\
\text { sources }\end{array}$ & 11.1 & 5.7 & 7.6 \\
$\begin{array}{c}\text { Group } \\
\text { sources }\end{array}$ & 33.3 & 21.6 & 28.8 \\
Unknown & 0 & 1.1 & 4.5 \\
\hline
\end{tabular}

countries, and it was there that news sources talked about what was happening.

Going over the articles published by the Portuguese press, mainly daily press, there are a significant number of texts in which the title has a European country's name, especially Spain and Germany: 'Infectious outbreak in Germany is not Spanish' (Jornal de Notícias, 28 May 2011); 'Bacteria in Germany has already made ten deadly victims' (Público, 29 May 2011); 'Germany believes sprouted seeds and beans are E. coli's origin' (Público, 11 June 2011); 'E. coli outbreak is nearing the end in Germany' (Jornal de Notícias, 5 July 2011). Therefore, the news' angle is determined previously, which means journalists need to hear sources that are in some way connected to the events. If Portugal was not affected by the outbreak, news sources could not have been the leading actors. They could only explain some preventive measures towards the events in Europe (Table 3).

Victoria Camps $(1998)^{13}$ believes that the twentyfirst century will belong to women. If we look into analyzed newspapers as a reflection of the social tissue, this optimistic idea is not fulfilled. News articles in our corpus show a high number of male sources. This is probably connected to the sources' status, which is essentially official. There is a wide minority of female sources (see Table 4). There is also a considerable amount of collective sources. This kind of source is pretty common through the 
speech of WHO and health authorities: Expresso $(33.3 \%)$, Público $(21.6 \%)$, and Jornal de Notícias $(28,8 \%)$.

\section{Conclusions}

Throughout the outbreak of E. coli, the Portuguese press developed a news process based on probabilities. One day they were writing that all 'had origin in Spanish cucumbers sold in Hamburg's central market' (Jornal de Notícias, 27 May 2011), the other they wrote: 'It seems unlikely that exported Spanish cucumbers are in the origin of E. coli, as news have been telling. This outbreak has already killed six people and affected hundreds, in Northern Germany'. This uncertainty did not end until July, when this subject disappeared from media stages. Official sources were not expected to act on suppositions, but Germany official sources were jumping on convictions that fast turned into doubts. On the one hand, journalists quoted political sources without any kind of critique. So they thickened people's fear, leading them not to eat vegetables. When something is ambiguous, the best way to deal with it is being precautious. One does not travel to countries where an outbreak seems to be developing, and one does not buy products under suspicion.

As for official sources behaviour, when it comes to risk communication it was clear that there was an absence of strategy built upon a safe diagnostic. Immediate reaction and the multiplication of explanations have discredited their role of public health protectors, have confounded people, and affected media relations. Besides, a wrong intervention from these sources may have compromised a future need for risk communication in Europe, because authorities' behaviours have been discredited. Moreover, this is not an isolated case, if we look into recent problems in risk management of an Influenza A pandemic in 2009. ${ }^{14}$ Under these circumstances, one may have thought that official sources would be cautious on their diagnosis, defining a responsible coherent communication strategy, as well as combining risk and crisis communication techniques towards an emergency that was already an installed crisis.

When it comes to sources, more than half were identified, meaning we know their name, position, and place where they come from. This would be a positive characteristic of news coverage, if there were not a significant number of unidentified sources. This can show that some sources were uncomfortable in personally assuming any information. That said, they did it on behalf of an organization. There are no anonymous sources whatsoever.

Looking at those who talk to/with journalists, one can see that there is not a wide plurality of sources. This reality is more evident with national sources than with international sources. Foreign sources are usually quoted through other media or media outlets, and they are diverse: because they talk from different geographical places or because they are quoted by several media. In Portugal, there is a trend to quote the same sources who are usually official. That so-called 'news sources brotherhood', selected among an elite, promotes a thigh agenda setting effect. Consequently, there is a 'spiral of silence', meaning the silence of some groups that could be important sources, like specialists. But it would have been positive to give voice to some other sources. It would have been productive to listen to specialized sources who could explain this uncertainty on the outbreak's causes. That was not the journalists' option. Official sources were valued over others. They choose two speeches, growing in parallel: either trying to calm people down ('In Portugal there are no reasons for alarm, say the authorities', Jornal de Notícias 31 May 2011); or criticizing Germany's communication strategies ('In Portugal, Francisco George criticized Germany's way of acting, saying there were "many communication errors" in their response, mainly by lack of consistency and speed', Jornal de Notícias 17 June 2011).

In between sources uncertain speeches and newspapers uncritical position, we once again prove common citizens' weakness towards the news processes and the communication management of healthcare organizations.

\section{What lessons for healthcare managers?}

Pandemic threats have been a concern of international public health organizations in the past few years, since it could increase health costs and result in thousands of deaths. Academic research has showed us the need for developing effective risk perceptions through communication strategies, in order to avoid crises and to improve the delivery of health information to populations. ${ }^{15}$

Risk communication is an important tool when making public health policy and therefore international authorities should understand the impact communication might have on a pandemic situation. Communication mistakes may lead to an inadequate protection of the population, as communication efforts must educate, inform, motivate 
for protection, build trust in authorities, and avoid rumours.

Through our analysis, it seems that the E. coli outbreak in Europe was not framed within a risk communication plan. International authorities, namely in Germany, would speak based on assumptions and convictions, rather than in certainties and facts. There was no perceived strategy regarding communication, and the immediate response of public authorities and political sources leads us to conclude they were disoriented. The E. coli outbreak was overrated and it disappeared as suddenly as it came. In Portugal, the media we analysed followed this disorientation and promoted it, causing fear among the population and making people doubt the vegetables they would eat, which also had an economic impact.

Official sources should have known better, also because an effective approach in the present may prevent future situations. These crises' situations ask for an intervention from the Ministry of Health, experts, and professionals within the health field. The non-effectiveness of these organized and official sources may jeopardize their authority towards citizens, who become frightened and doubtful.

The development of a valuable risk communication strategy is crucial when it comes to public health organizations and political authorities. These sources are asked to balance their speeches between the release of information and the risk of promoting fear within the population. The E. coli outbreak happened short after a major international risk communication crisis: Influenza A organizations must be ready to deal with public health threats and also lean on the media to help them reassure populations.

\section{Appendix: $E$. coli's timeline}

Jornal de Notícias, 27 May 2011: Portugal does not buy 'deadly' cucumbers

German authorities 'say Spanish cucumbers would be the source of a fatal infectious outbreak on their territory': 'the infectious outbreak caused by a dangerous strain of Escherichia coli bacterium (...) had its origin on Spanish cucumbers sold on Hamburg's central market'.

Jornal de Notícias, 28 May 2011: Infectious outbreak in Germany is not Spanish

'It seems unlikely that Spanish cucumbers are the source of the outbreak that affected hundreds of people, killing six, in Northern Germany'.

Público, 28 May 2011: Food and Safety Authority studies the entrance of undermined cucumbers
Government admits there are no reasons for alarm in Portugal, but Food and Safety Authority is studying the possible entrance of Spanish cucumbers in Portugal.

Público, 29 May 2011: Bacterium in Germany has already made tem deathly victims

'On Thursday, Hamburg's Institute of Hygiene affirmed the bacteria has had origin in Spanish cucumbers sold in Hamburg's central market'.

Jornal de Notícias, 31 May 2011: Spanish cucumbers are still being sold

The number of deaths in Germany arises to 14, and there are now 1200 suspicious cases. Meanwhile, in Spain, the Government estimates Spanish farmers' losses are over 200 million euros and they have already asked for European Union's help. The tone of speech, in Portugal, is still calm: 'In Portugal there are no reasons for alarm, say the authorities'.

Público, 31 May 2011: Bacterium has already killed 14 people in Germany and the origin is still unknown

'It is not only the cucumbers: other raw vegetables, like tomatoes and lettuces, are also under suspicion in Northern Germany'. 'Although Spain was pointed out to be the source of undermined vegetables, the truth is that at least yesterday the outbreak's origin was still unknown'.

Jornal de Notícias, 1 June 2011: Bacterium's source is not Spanish

Hamburg's Health Minister said to a German daily newspaper that 'lab results indicate Spanish cucumbers are not the source' of E. coli. 'We still do not know the outbreak's origin' said the Health Minister. However, according to the Portuguese head of National Health Board, German authorities 'admit as probable source of the outbreak the eating of raw vegetables undermined by that bacterium'.

Público, 1 June 2011: One needs to be careful with trips to Germany

'First there was an alarm towards the danger of eating Spanish cucumbers, now the head of Public Health College from National Health Board, Mário Jorge Santos, says one needs to be careful when travelling to Germany'. 'The first analyses to Spanish cucumbers which were suspects of being the origin of the outbreak were negative'.

Jornal de Notícias, 2 June 2011: Portugal analyzes cucumbers to rule out bacteria

'Seventeen deaths, millions of euro in losses, diplomatic conflicts and many uncertainties draw the European crisis outlined by E. coli on vegetables'. Portugal still does not have any records of the bacteria, yet several samples of national cucumbers started being analysed at National Health Institute Dr Ricardo Jorge. 
Público, 2 June 2011: E. coli's origin is still mysterious and infections spread

'Spanish cucumbers are officialy forgiven: European commission dropped the alert as for their consumption'. 'The outbreak's origin is still mysterious, and possibly active'. 'German health authorities have to do a real detective job to find out E. coli's origin'.

Jornal de Notícias, 3 June 2011: Three Portuguese are suspects of infection in Germany

'Three Portuguese are being submitted to exams because they just returned from Germany and they feel sick'. However, Francisco George insists 'there are no cases, there are people who felt sick'.

Público, 3 June 2011: E. coli which cause the outbreak in Germany has DNA from a more toxic bacterium

The bacterium that is infecting people in Germany 'seems to be a new strain of Escherichia coli'. 'From German and Chinese labs came the confirmation that this is a new strain; but World Health Organization sent a confuse message: is it a new strain or just a "really rare" one?' 'While the detective and scientific work is going on, the war in Brussels and other capitals gets worse'.

Expresso, 3 June 2011: Epidemic: The guilty is other. But it is unknown

WHO confirms 'the strain of E. coli detected on patients is totally new and highly toxic'. 'It is only known that this strain is a genetic mutation and is resistant to several antibiotics'.

Público, 4 June 2011: Two of the three suspect cases in Portugal were not confirmed

Two of the three suspect cases in Portugal were not confirmed; the third patient is still hospitalized but is recovering.

'Although German health authorities first related the outbreak to Spanish cucumbers' contamination, the origin of the infection is still unknown, being the most probable hypotheses the consumption of raw vegetables' undermined by that bacterium or untreated water'. 'Even though Spanish cucumbers are no longer the suspects, the consequences of this first theory are still huge'. 'There was a large decrease in vegetables' sales, and farmers are throwing cucumbers, lettuces and tomatoes in to the garbage'.

Público, 5 June 2011: WHO data put the hypothesis of person-to-person contagion on E. coli's outbreak

'World Health Organization data on E. coli in Europe arise the possibility of person-to-person transmission'. 'The outbreak's source is still unknown'.

Público, 6 June 2011: E.coli: sprouted seeds are the probable origin of the outbreak
'Sprouted seeds from Germany, Low Saxon, are the probable cause for E. coli's outbreak. The outbreak has already killed 22 people in Europe, 21 in Germany alone'.

Público, 7 June 2011: First tests to sprouted seeds are negative as for E. coli

German authorities declared 23 of the 40 samples of sprouted seeds were negative as for the presence of E. coli.

Público, 8 June 2011: EU countries demand full compensation of farming losses

'Although cucumbers were cleared out as the origin of the most dangerous outbreak of E. coli, Hanover authorities have warned not to eat them. The same goes to tomatoes and lettuces produced in Europe. This caused panic and a big decrease on vegetables' consumption'. 'The somewhat wrong crisis management from German authorities was criticized by the European health commissioner, since there were more than two thousand people infected and 23 deaths and the outbreak's origin is still unknown'.

Público, 9 June 2011: New E. coli infections are decreasing but EU advises Germany to ask for help

'European Commission has announced that financial compensation for European farmers has risen from 150 million to 210 million euro. Farmers have suffered with the decrease on sales due to E. coli's epidemic and the constant alerts from Germany'.

Público, 10 June 2011: E. coli is detected on a cucumber and makes its 30 th victim

'E. coli, which is causing a severe outbreak in Germany, makes its 30th victim. This was announced by German authorities, on the day the bacterium was first found on a cucumber skin eaten by a family who got sick'.

For the time being, 'the suspicion on sprouted seeds has changed country yesterday: Dutch authorities have announced the detection of an E. coli strain on beetroot sprouted seeds'.

Público, 11 June 2011: Germany believes sprouted seeds are $E$. coli's origin

'German authorities said yesterday that the "most probable" cause for E. coli's outbreak would be sprouted seeds produced in the country, on a Low Saxon farm. This farm is already sealed and under investigation, since last week, and the outbreak has now caused the death of 31 people and infected almost three thousand'. In the mean time, Russia has promised to stop embargo to European Union vegetables.

JN, 11 June 2011: Sprouted seeds are the outbreak's origin

'E. coli's deathly strain was found on soy sprouted seeds, German authorities have announced. The 
outbreak's probable source was identified, and restrictions to eating cucumbers, tomatoes and lettuce were dropped'.

Público, 12 June 2011: Farm were E. coli was found 'does not have flaws'

'The panic caused by the outbreak promoted tension in Germany and in their relationships with European neighbors, since the authorities first pointed fingers to Spanish cucumbers'.

JN, 12 June 2011: Sprouted seeds confirmed as the epidemic's source

'German health authorities have officialy confirmed lab results comprove E. coli's outbreak was caused by undermined sprouted seeds/beans, grown on a biological farm in Germany'.

Meanwhile, in Thailand, health authorities said they found E. coli on European cauliflowers.

JN, 15 June 2011: Food bacterium kills first child

'A two year old child died yesterday, in Northern Germany, infected with E. coli. This is the first child victim, now part of the 36 deaths'.

JN, 16 June 2011: One more elderly victim of infection

One more person died with E. coli, this time a 90year old. 'German health authorities' way of acting is criticized both internationally and nationally'.

'Towards the outbreak, and since German authorities still do not have a proven cause, Russia keeps their embargo to European vegetables, contradicting what they had promised on the European Union summit a week ago'.

Público, 17 June 2011: New strain of E. coli affects seven children in Northern France

Some children got sick with severe food poisoning caused by a 'rare strain' of E. coli, after having eaten frozen hamburgers sold by Lidl. 'Regional health administration declared to "be sure this is not the same strain detected on sprouted seeds" which caused infections in Germany'.

JN, 17 June 2011: E. coli takes children to the hospital

This time it was in Lille, France. Six children were hospitalized 'due to a food poisoning connected to a rare strain of E. coli, after having eaten frozen hamburgers'. According to French authorities, these cases are not related to the outbreak in Germany. In Portugal, Francisco George has criticized Germany's way of acting, saying there were 'a lot of communication errors' in Germany's first response, mainly due to 'a lack of consistency and fastness'.

Expresso, 18 June 2011: E. coli: 'The outbreak is still not under control'

'The lack of convincing explanations on E. coli's source and it being so dangerous lead the head of Portuguese National Health Board to say that "all food is suspect, including water"'.
JN, 28 June 2011: Sprouted seeds are suspects of E. coli

'Health authorities from several countries, namely Holland and the UK, are more and more sure that E. coli's outbreak is connected to the consumption of raw or undercooked sprouted seeds/ beans. This outbreak has caused for the death of 47 people'.

JN, 5 July 2011: E. coli's outbreak is nearing the end in Germany

Robert Koch Institute has announced there are 'several evidences that point out to the end of the infectious outbreak'. 'The decrease in sales has led the European Union to create a special fund to support farmers and to review the food alert system, in order to avoid panic without scientific base'.

JN, 6 July 2011: Greek hay seeds are the new clue for E. coli

'A whole bunch of Greek hay seeds that came from Egypt to Germany in 2009 seem to be responsible for the outbreak of E. coli, according to the European Food and Safety Agency'. Consequently, European Union has announced 'the temporary prohibition on imports of sprouted seeds/beans and Greek hay seeds from Egypt'.

JN, 7 July 2011: EU declares E. coli's outbreak controlled

\section{Acknowledgements}

This work is funded by FEDER funds through the Programa Operacional Factores de Competividade COMPETE (FCOMP-01-FEDER-0124-009064) and national funds through FCT - Fundação para a Ciência e Tecnologia under the project "Disease in the News" (PTDC/CCI-COM/103886/2008).

\section{References}

1. Benoit WL. Image repair discourse and crisis communication. Public Relations Rev 1997;23(2):177-86.

2. Reynolds B, Seeger M. Crisis and emergency risk communication as an integrative model. J Health Commun 2005;10:43-55.

3. Seeger M. Best in crisis communication: an expert panel process. J Appl Commun Res 2006; 34(3):232-44.

4. Salgado P, Ruão T, Machado S. Managing reputation risk: creating safety nets through corporate communication programs. IAMCR Conference, University of Minho, Portugal, 2010.

5. Williams D, Olaniran B. Expanding the crisis planning function: introducing elements of risk communication to crisis communication practice. Public Relations Rev 1998;24(3):387-400.

6. Vaughan E, Tinker T. Effective health risk communication about pandemic influenza for vulnerable populations. Am J Public Health 2009;99(2):324-32. 
7. Fischhoff B. Risk perception and communication unplugged: twenty years of process. Risk Anal 1995; 15:137-45.

8. Atkin C, Wallack L. Mass communication and public health complexities and conflicts. Newbury Park, CA: Sage; 1990.

9. Seale C. Health and media. Malden, MA: Blackwell Publishing; 2004.

10. Paek HJ, Hilyard K, Freimunth V, Barge J, Mindlin M Public support for government actions during a flu pandemic: lessons learned from a statewide survey. Health Promot Pract 2008;9(4):60-72.

11. Lopes F, Ruão T, Pinto-Coelho Z. A Doença em Notícia: linhas de um projecto sobre a construção e monitorização da noticiabilidade sobre doenças.
Comunicação apresentada no VI SOPCOM. Lisboa: Universidade Lusófona; 2009 April 15.

12. Lopes F, Ruão T, Marinho S, Araújo R. Jornalismo de Saúde e Fontes de Informação - uma análise dos jornais portugueses entre 2008 e 2010. Derecho a Comunicar 2011;2:100-20.

13. Camps V. El siglo de las mujeres. Spain: Ediciones Cátedra, SA; 1998.

14. Lopes F, Ruão T, Marinho S. Gripe A na Imprensa Portuguesa: uma doença em notícia através de uma organizada estratégia de comunicação. Observatório (OBS*) J 2010;4(4):139-56.

15. Moreira P. A framework for responsive health policy and corporate communication. Corporate Commun Int J 2007;12(1):8-24. 